\title{
The influence of heating on the nutritive value of soya-bean meal for ruminants*
}

\author{
By H. TAGARI, I. ASCARELLI AND A. BONDI \\ Faculty of Agriculture, Hebrew University, Rehovot, Israel

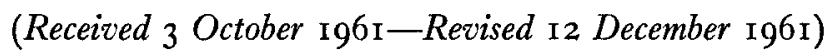

It has been generally assumed that the nutritive value of protein feeds for ruminant animals is not influenced by the chemical and physical properties of the proteins. Several recent investigations have shown that proteins with a high solubility are degraded in the rumen to ammonia at a rate too rapid for efficient utilization. The rumen micro-organisms can then utilize only a relatively small part of the liberated ammonia for synthetic purposes. Excess ammonia diffuses into the blood and is converted in the liver into urea, and most of this urea is excreted in the urine, only a small amount being returned to the rumen through the saliva. Evidence was given by El-Shazly (1958) and Jasiorowski ( 1960 ) that the protein in green forages and hays is utilized to a greater extent when it is of low solubility, highly soluble proteins from similar feeds being utilized to a lesser degree. The beneficial effect of reducing the solubility of protein in concentrates by heating was first recognized by Chalmers, Cutherbertson \& Synge (1954) and Chalmers \& Synge (1954), and confirmed by Whitelaw, Preston \& Dawson (I96I) who found considerable advantage in the use of heat-treated groundnut meal in comparison with untreated groundnut meal.

It is well known that the full utilization of soya-bean meal for poultry feeding is obtained only by proper heating. The causes generally recognized as responsible for the improvement of soya-bean meal by heat treatment are irrelevant for ruminants. Since the solubility of protein of soya-bean meal decreases considerably on heating, we compared the utilization by ruminants of protein of soya-bean meals subjected to different heat treatments. Preliminary experiments carried out in a miniature artificial rumen showed a very significant decrease in the amount of ammonia liberated from heated soya-bean meal in comparison with the untreated soya-bean meal. These results led us to examine the utilization by sheep of three different kinds of soya-bean meal, the rate of liberation of ammonia in the rumen, changes in blood-urea concentration and nitrogen balance being used for assessing their value.

\section{EXPERIMENTAL}

Animals. Four I-year-old rams of the Awasi breed were used, weighing at the beginning of the experiment $45^{-49} \mathrm{~kg}$.

Soya-bean meals. Three kinds of soya-bean meal were tested. In their preparation,

* Part of a Ph.D. thesis to be submitted by H.T. to the Faculty of Agriculture, The Hebrew University, Jerusalem, Israel. 
soya-bean seeds underwent first a heat treatment at $70-80^{\circ}$ for 20 min followed by dehulling, flaking and defatting with light petroleum (b.p. $50^{\circ}$ ) for $3 \mathrm{~h}$. Subsequent treatments were:

(I) Soya-bean meal $\mathrm{F}$ was prepared by evaporating the solvent from the flakes at room temperature, thus avoiding any additional heating.

(2) Soya-bean meal UT (a commercial untoasted soya-bean meal) was prepared by removing the solvent from the flakes at $80^{\circ}$ for $10 \mathrm{~min}$.

(3) Soya-bean meal $\mathrm{T}$ (a commercial toasted soya-bean meal) was prepared by steaming the flakes at $120^{\circ}$ for $15 \mathrm{~min}$.

Feeds. Bersim clover hay (Trifolium alexandrinum L.) was the only feed when rumen liquor was required from the rams for the preliminary in vitro tests.

Feeding experiments were carried out with two different diets. Both supplied the energy requirements according to Brody's (1945) standard but one supplied the amount of protein as fixed by the same standard and the other double that amount. The latter diet, which will be referred to as the ' $200 \%$ diet', was composed of $200 \mathrm{~g}$ soya-bean meal ( $45 \%$ protein) and about I $\mathrm{kg}$ foxtail millet (Setaria italica Beauv.) hay $(7 \cdot 5-8 \cdot 5 \%$ protein). Soya-bean meal supplied about $60 \%$ of the digestible protein of this diet. The diet supplying the theoretical protein requirement, which will be referred to as the ' $100 \%$ diet', was composed of foxtail millet hay and soyabean meal in amounts such that each would supply $50 \%$ of the digestible protein, the energy requirement being fulfilled by the addition of a proper amount of cottonseed hulls whose protein is completely indigestible (Morrison, 1954). The whole of the soya-bean meal and the cottonseed hulls were given at about $7.30 \mathrm{a} . \mathrm{m}$.; the hay was divided into two unequal portions, the smaller one being given after the concentrates had been eaten, and the other at about 3 p.m. The rams were given each kind of soya-bean meal in turn.

Sampling. Rumen liquor was removed by suction through a stomach tube before the morning feeding and at intervals of from $\mathrm{I}$ to $2 \mathrm{~h}$ for the next $8 \mathrm{~h}$. Blood samples for urea determination were withdrawn from the jugular vein before the morning feed, and later at intervals of from I to $3 \mathrm{~h}$, the intervals being longer during the first part of the day and shorter during the afternoon. Heparin was used throughout as an anticoagulant.

Chemical methods. The dye absorption test, developed by Frölich (1954) for the evaluation of the quality of processed soya-bean meal for poultry nutrition, was used with the modification of Olomucki \& Bornstein ( 1960$)$. For the determination of the solubility of the protein in soya-bean meal, I $g$ samples ground in a Wiley laboratory mill with a 60-mesh sieve were mechanically stirred for $\mathrm{I} h$ at $38^{\circ}$ with $\mathrm{Io} \mathrm{ml}$ artificial saliva $(\mathrm{pH} 7 \circ 0)$ prepared by the method of Huhtanen, Saunders \& Gall (I954) and the $\mathrm{N}$ content of the supernatant solution was determined by the macro-Kjeldahl procedure after centrifugation at $2000 \mathrm{~g}$ for to $\mathrm{min}$.

Artificial-rumen technique. Liberation of ammonia from soya-bean meals was measured by Conway's (1957) method in an artificial miniature rumen modified from the one designed by Huhtanen et al. (1954). Details of this apparatus will be given elsewhere. A $200 \mathrm{mg}$ portion of the meal was incubated with $10 \mathrm{ml}$ rumen liquor 
for $4 \mathrm{~h}$ and the ammonia was measured after acidification with trichloroacetic acid to a final concentration of $10 \%$, and centrifugation. Urea in $0.3 \mathrm{ml}$ samples of blood was also measured by Conway's method.

\section{RESULTS AND DISCUSSION}

Classification of the meals. The samples of soya-bean meal can be characterized according to the results of the dye absorption test (Table I): samples F and UT as 'raw or much underheated', and sample $\mathrm{T}$ as 'properly heated'. The results of the

Table I. Dye absorption and protein solubility of the different soya-bean meals

$\begin{array}{lcc}\text { Meal } & \begin{array}{c}\text { Cresol red } \\ \text { absorbed } \\ (\mathrm{mg} / \mathrm{g})\end{array} & \begin{array}{c}\text { Solubility of } \\ \text { protein* }\end{array} \\ \text { F } & 2 \cdot 60 & 6 \mathrm{r} \cdot 2 \\ \mathrm{UT} & 3 \cdot 00 & 40.7 \\ \mathrm{~T} & 4 \cdot 05 & \mathrm{I} \cdot \mathrm{I}\end{array}$

* As percentage of total crude protein.

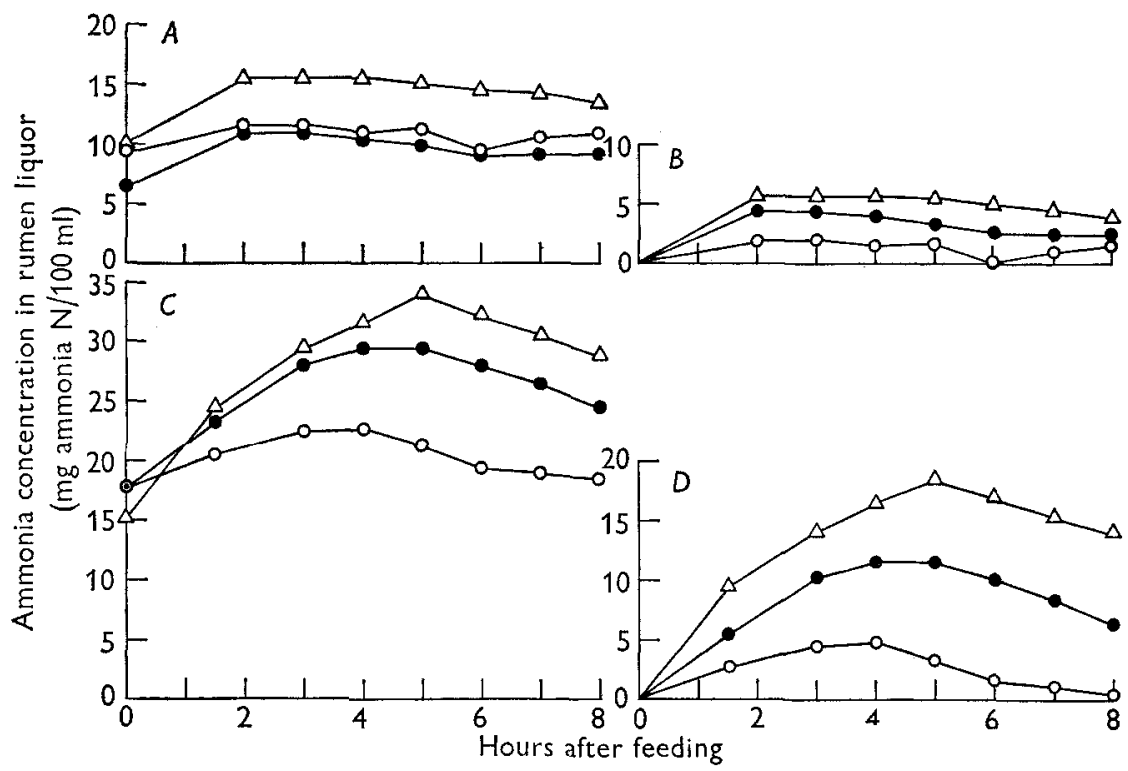

Fig. I. Ammonia concentration in the rumen contents of sheep given a diet containing different soya-bean meals and providing protein at the theoretical requirement (top) or twice the theoretical requirement (bottom). All time intervals were measured from the morning feeding time. $A, C$, total concentration; $B, D$, difference from initial concentration; $\Delta-\Delta$, meal $F ; \bullet-\bullet$, meal UT; $\circ \circ$, meal $T$. Each curve was drawn from results for each of three $(A, B)$ or four $(C, D)$ sheep on 4 different days.

determinations of protein solubility (Table $\mathrm{I}$ ) clearly show the pronounced influence of the different heat treatments: heating caused a very considerable diminution of the solubility of soya-bean protein.

In vitro liberation of ammonia from the meals. The amounts of ammonia $\mathrm{N}$ liberated 
by incubation were: meal $\mathrm{F}_{13} 33$, meal UT I $_{1} \cdot 05$, meal $\mathrm{T} 3.72 \mathrm{mg} / \mathrm{I00} \mathrm{ml}$. The values are means of six determinations carried out on different days with rumen liquor withdrawn from different sheep.

In vivo experiments. Levels of free ammonia in the rumen liquor are given in Fig. I and urea concentrations in blood are given in Fig. 2. The results are expressed both as absolute amount and as excess above the initial level. The curves show clearly that the ammonia concentrations in rumen liquor and the urea concentrations in blood

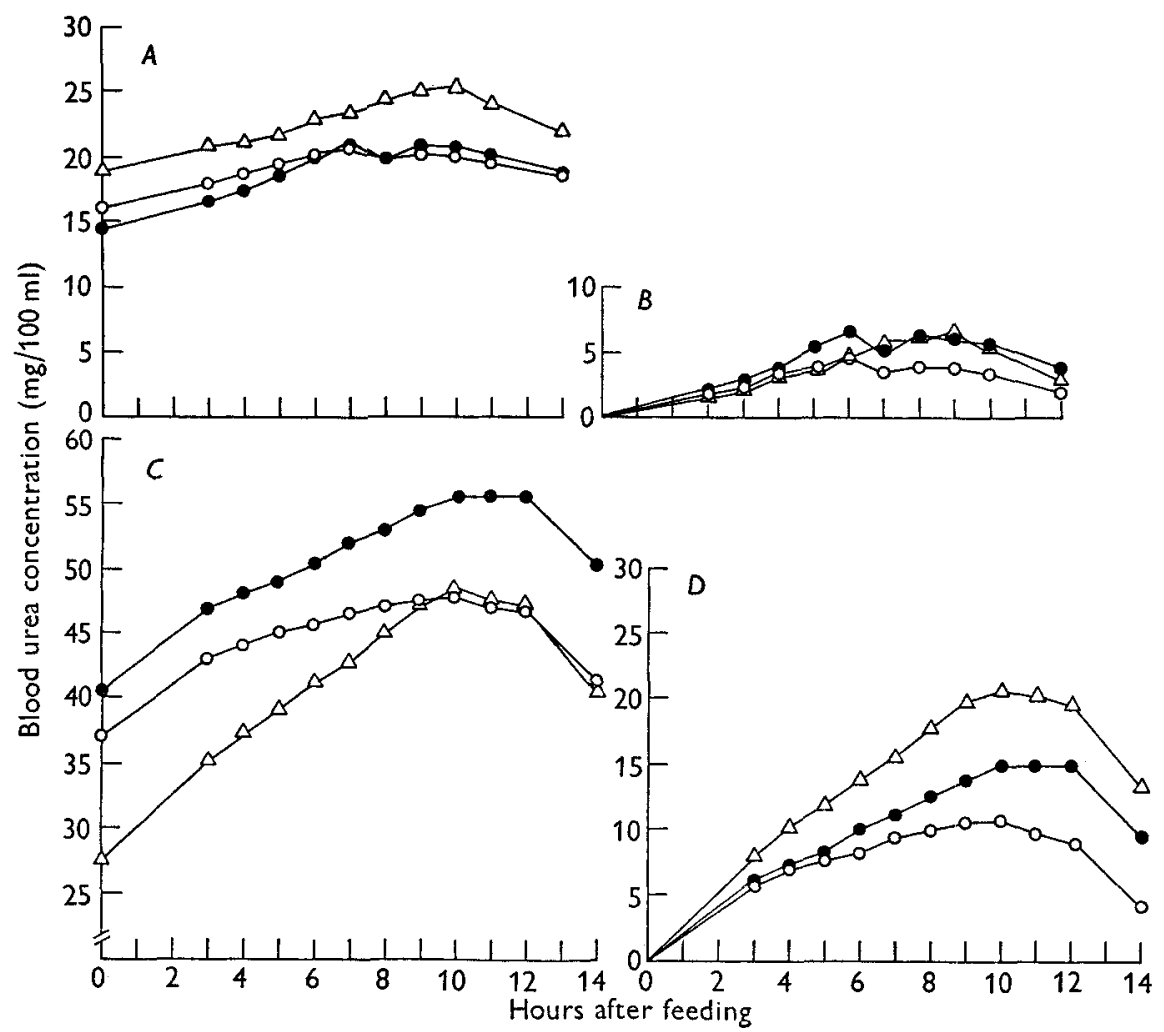

Fig. 2. Blood urea concentration in sheep given a diet containing different soya-bean meals and providing protein at the theoretical requirement (top) or twice the theoretical requirement (bottom). All time intervals were measured from the morning feeding time. $A, C$, total concentration; $B, D$, difference from initial concentration; $\triangle-\triangle$, meal F; $\bullet \bullet$, meal UT; $\circ-0$, meal $T$. Each curve was drawn from results for one sheep on 3 different days $(A, B)$ or for each of four sheep on 2 different days $(C, D)$.

were much higher with the $200 \%$ diet than with the $100 \%$ diet. Generally, the susceptibility of the meals to liberation of ammonia rose in the order $\mathrm{T}<\mathrm{UT}<\mathrm{F}$. This trend is particularly clear in Figs. г $B$, I $D, 2 D$, where the values are expressed as increases above the initial levels. An unexpected deviation from this trend is shown in Fig. $2 C$ : the blood urea curve for sheep getting meal $\mathrm{F}$ surprisingly began at a low level, although this kind of meal, from which the highest amount of ammonia was liberated, had been given to the animals for an extensive period. A possible explanation of this finding may be based on the following assumption: when ammonia levels 
in the rumen are higher (as when this meal is eaten), diffusion of ammonia through the rumen wall to the blood will be greater, a greater amount of urea will be formed and urea excretion will therefore be at a higher level. When the other kinds of soyabean meal are eaten, less protein is lost by this route and more protein reaches the abomasum and undergoes the usual process of digestion. The results obtained by Schmidt-Nielsen \& Osaki (1958), showing that ingestion of diets from which greater amounts of ammonia are liberated increases the efficiency of the mechanism of renal regulation of urea excretion, are in agreement with our finding. Further support for the above explanation is found in the results of the $\mathrm{N}$ balance experiments, which are discussed below.

The maximal concentration of ammonia was reached from 2 to $4 \mathrm{~h}$ after feeding when the protein content of the diet was equal to the theoretical requirement; when double that amount of protein was given, the maximal ammonia concentration was found from 4 to $5 \mathrm{~h}$ after feeding. When the $200 \%$ diets were given, the peaks were sharper, the curves being steeper on both sides. This finding was particularly apparent with meal $\mathrm{F}$. The highest level of urea in the blood was found $4 \mathrm{~h}$ after the peak in rumen ammonia concentration was reached. This time lag is in accordance with the findings of Lewis (1957) and Meyer \& Rustige (1959).

\section{Table 2. Mean values for four rams for nitrogen digestibility and balance with diets containing the various soya-bean meals}

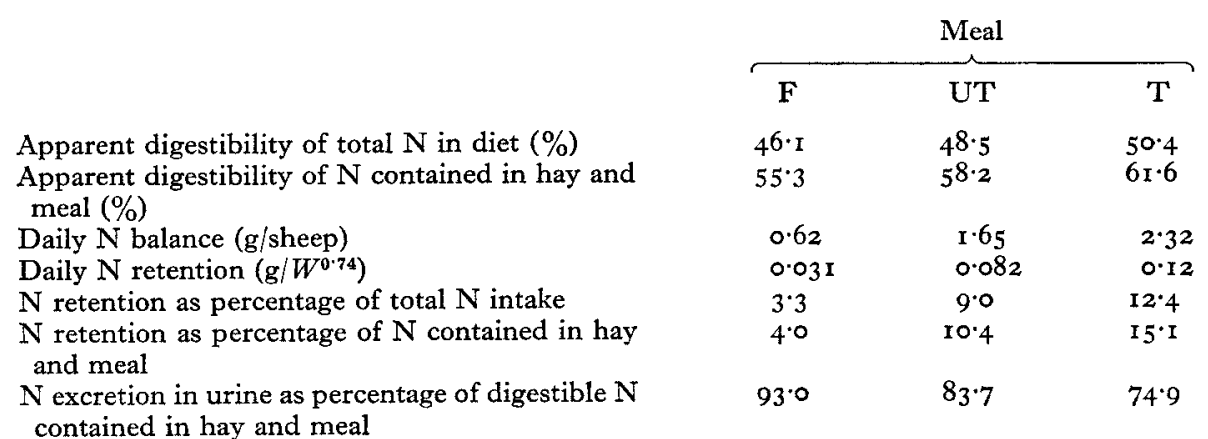

The parallelism between the curves representing ammonia liberation in the rumen and urea concentration in the blood found by these authors is confirmed again in our work. Thus new support is given to these authors' suggestion that blood urea concentration may be used for assessing the value of food protein for ruminants.

Measurement of $N$ balance. Results are presented in Table 2. The apparent digestibility coefficients of the meals showed a small increase in the order $\mathrm{F}<\mathrm{UT}<\mathrm{T}$. The absolute values of the digestion coefficients were comparatively low, as the presence of considerable amounts of cottonseed hulls in the diet caused a decrease of the digestibility. The values of the percentage $\mathrm{N}$ retention were low, as the experiments were carried out with adult sheep. Since the protein in cottonseed hulls is indigestible, it seems justifiable to calculate the percentage $\mathrm{N}$ retention on the basis of the protein contained in the meal and hay only. The values for $\mathrm{N}$ retention 
by individual sheep calculated in this way are given in Table 3. Statistical analysis of the values in this table showed that $\mathrm{N}$ retention with meal $\mathrm{F}$ was significantly different from that with meal UT. Difference in retention with meal UT and meal T was statistically significant only if results for sheep 4, whose behaviour was peculiar, were omitted, but the clear trend of the retention coefficients towards the order $\mathrm{T}>\mathrm{UT}>\mathrm{F}$ confirms the negative effect of the formation of ammonia in the rumen in large amounts. The positive influence of heat treatment of soya-bean meal on the utilization of its protein for the specific requirements of maintenance is clearly apparent from all the results given in Table 2.

Table 3. Individual values for four rams for nitrogen retention, as percentage of $N$ in hay and soya-bean meal, with diets containing the different soya-bean meals

\begin{tabular}{|c|c|c|c|c|c|}
\hline \multirow[b]{2}{*}{ Meal } & \multicolumn{4}{|c|}{ Sheep no. } & \multirow[b]{2}{*}{ Mean } \\
\hline & I & 2 & 3 & 4 & \\
\hline $\mathrm{F}$ & 47 & 2.4 & 0 & $8 \cdot 8$ & 4.0 \\
\hline UT & I I ' I & $14 \% 7$ & $6 \cdot 9$ & $8 \cdot 7$ & 10.4 \\
\hline $\mathrm{T}$ & I 5.9 & $17 \cdot 3$ & I6.4 & II 0 & I $5 . \mathrm{I}$ \\
\hline
\end{tabular}

Miller \& Morrison ( 1944 ) found a similar positive effect of heat treatment of soyabean meal by measuring $\mathrm{N}$ stored by growing lambs. Their assumption that this effect is caused only by the higher digestibility of heated soya-bean meal cannot be accepted as sufficient: it is our view that the resistance of the heated soya-bean meal to deamination in the rumen is the main factor responsible for its higher food value. This opinion is also supported by the partition of the digested protein between the two fractions excreted in urine and retained in the body: the percentage of digestible protein excreted in the urine was 93 with the diet containing meal $\mathrm{F}$, and only 75 with the diet containing meal $\mathrm{T}$.

The results of our experiments clearly show that the main factor determining the different efficiencies of processed and non-processed soya-bean meals is their different solubility in rumen liquor. The changes in solubility caused by different heat treatments of soya-bean meal are large in comparison with those caused by similar treatments of other meals: in soya-bean meal the toasting reduced the solubility from $6 \mathrm{I}$ to $13 \%$, whereas Whitelaw et al. (196I) found that heat treatment of groundnut meal reduced the solubility only from 84 to $66 \%$.

The practical advantage of the use of heat-treated soya-bean meal is apparent from the results of Miller \& Morrison's (I944) growth experiments with lambs. The striking difference found in our work between meals $\mathrm{F}$ and $\mathrm{T}$ is a clear indication of the effect that the heat treatment may have on feeds for ruminants.

\section{SUMMARY}

1. The utilization by four rams of protein of soya-bean meals subjected to different heat treatments was compared.

2. Heating of soya-bean meal caused a very considerable decrease in the solubility of its protein. 
3. In vitro and in vivo experiments showed a striking decrease in the amount of ammonia liberated by the rumen micro-organisms from heated soya-bean meal in comparison with the untreated soya-bean meal.

4. Parallelism between ammonia liberation in the rumen and urea concentration in the blood was established.

5. The apparent digestibility coefficients of protein in heated soya-bean meal were somewhat higher than in untreated soya-bean meal.

6. Nitrogen retention by adult sheep from diets containing heated soya-bean meal was considerably higher than from diets containing untreated meal.

7. Commercial untoasted soya-bean meal, which is heated during removal of the solvent, showed an intermediate behaviour between non-heated and properly toasted meals in regard to all properties examined.

8. The following explanation of the positive influence of heat treatment is proposed: ammonia is liberated from untreated soya-bean meal to such an extent that the micro-organisms cannot use it profitably for synthetic purposes, a greater part of the ammonia diffusing through the rumen wall to the blood and therefore being wasted.

\section{REFERENCES}

Brody, S. (1945). Bioenergetics and Growth, p. 478. New York: Reinhold Publishing Corp.

Chalmers, M. J., Cuthbertson, D. P. \& Synge, R. L. M. (1954). F. agric. Sci. 44, 254.

Chalmers, M. J. \& Synge, R. L. M. (1954). F. agric. Sci. 44, 263.

Conway, E. J. (1957). Microdiffusion Analysis and Volumetric Error, $4^{\text {th }} \mathrm{ed}$. London: Crosby Lockwood and Son Ltd.

El-Shazly, K. (1958). F. agric. Sci. 51, 149.

Frölich, A. (1954). Nature, Lond., r74, 879.

Huhtanen, C. N., Saunders, R. K. \& Gall, L. S. (1954). F. Dairy Sci. 37, 328.

Jasiorowski, H. (1960). Proc. int. Grassld Congr. vıı. Reading, p. 538.

Lewis, D. (1957). F. agric. Sci. $4^{8}, 438$.

Meyer, H. \& Rustige, J. (1959). Zbl. VetMed. 6, 872.

Miller, J. I. \& Morrison, F. B. (1944). F. agric. Res. 68, 35.

Morrison, F. B. (1954). Feeds and Feeding, 2 Ist ed. reprinted, p. Iogo. Ithaca, New York: The Morrison Publishing Co.

Olomucki, E. \& Bornstein, S. (1960). F. Ass. off. agric. Chem. 43, 440.

Schmidt-Nielsen, B. \& Osaki, H. (1958). Amer. F. Physiol. 193, 657.

Whitelaw, F. G., Preston, T. R. \& Dawson, G. S. (1961). Anim. Prod. 3, 127. 